\title{
Accelerated Life Test for Photovoltaic Cells Using Concentrated Light
}

\section{Daniel Tudor Cotfas, Petru Adrian Cotfas, Dan Ion Floroian, and Laura Floroian}

Electrical Engineering and Computer Science Faculty, Transilvania University of Brasov, 500036 Brasov, Romania

Correspondence should be addressed to Daniel Tudor Cotfas; dtcotfas@unitbv.ro

Received 14 April 2016; Revised 7 June 2016; Accepted 3 July 2016

Academic Editor: Prakash Basnyat

Copyright ( 2016 Daniel Tudor Cotfas et al. This is an open access article distributed under the Creative Commons Attribution License, which permits unrestricted use, distribution, and reproduction in any medium, provided the original work is properly cited.

This paper presents a new method developed to significantly reduce the necessary time for the ageing tests for different types of photovoltaic cells. Two ageing factors have been applied to the photovoltaic cells: the concentrated light and the temperature. The maximum power of the photovoltaic cells was monitored during the ageing process. The electrical dc and ac parameters of the photovoltaic cells were measured and analyzed at 1 sun irradiance, before and after the test stress. During the test, two photovoltaic cells are kept at maximum power point and the other two are kept at open circuit voltage point. The method is validated through the results obtained for the monocrystalline silicon solar cell.

\section{Introduction}

The reliability and durability are two important factors for the new photovoltaic cells and panels, today perhaps at least as important for them as the price per watt. The lifetime of new photovoltaic cells such as, but not only, the multijunction cells used in concentrated light whose efficiency is $46 \%$ [1] and the very promising perovskite solar cells whose efficiency increases very quickly at $20.1 \%$ [2], is not known.

Therefore, a predictive model for the lifetime and the behavior of the new photovoltaic cells and panels is very important for producers as well as for customers. The accelerated ageing test for the photovoltaic cells and panels is one of the main analyses which are the base of the predictive model $[3,4]$.

There are several methods to realize the accelerated ageing test for photovoltaic cells and panels indoors, such as

(i) Damp Heat Test $(\mathrm{DH})$ : the ageing factors are the temperature and the relative humidity; the values for these two factors are $85^{\circ} \mathrm{C}$ and $85 \%$; the time for the ageing test is over 2000 hours [5];

(ii) Highly Accelerated Stress Test (HAST): the ageing factors are the temperature and the relative humidity, but their values grow in comparison to $\mathrm{DH}$, so the temperature can be $110^{\circ} \mathrm{C}, 130^{\circ} \mathrm{C}$, or $150^{\circ} \mathrm{C}$, and the humidity can be $85 \%$ or $100 \%$; the increasing of the ageing factors values leads to the decrease of the time for the ageing test; in this case the time for the ageing test is around 400 hours;

(iii) step-stress accelerated ageing tests: the ageing factors are the temperature and the injected current to emulate constant illumination; the temperature can be $130^{\circ} \mathrm{C}, 150^{\circ} \mathrm{C}$, or $170^{\circ} \mathrm{C}$ and the value of the current is equal to the value of the short circuit current, $I_{\mathrm{sc}}$, at 1 sun multiplied with 700 or 1050; the test being made for multijunction solar cells [6];

(iv) thermal cycling test: this method uses the variation of the temperature between $-40^{\circ} \mathrm{C}$ and $85^{\circ} \mathrm{C}$ and the injected current to emulate constant illumination; the amount of the cycling varies in function of the upper limit of the temperature, 500 for $110^{\circ} \mathrm{C}, 1000$ for $85^{\circ} \mathrm{C}$, or 2000 for $65^{\circ} \mathrm{C}$; the injected current in the solar cell is equal to $1.25 \times I_{\mathrm{sc}} \times$ no. of suns [7];

(v) potential induced degradation (PID): the ageing factors for the photovoltaic modules are the external bias voltage, the temperature, and the relative humidity; their values are $1000 \mathrm{~V}, 50^{\circ} \mathrm{C}$, and $50 \%$ [5] or $600 \mathrm{~V}$, $65^{\circ} \mathrm{C}$, and $85 \%[8]$. 
The lifetime for the Si photovoltaic panels now is known and it is over 25 years [9]. The failure criterion is when its maximum power decreases with at least $20 \%$ from the initial maximum power [10].

Núñez et al. had defined a degradation failure criterion for the multijunction cells [11]. The failure limit is when the maximum power decreases with at least $2.5 \%$ from the initial maximum power. Núnez et al. considered that a power loss of up to $20 \%$ is generated by the other elements of the concentrator photovoltaic system.

The degradation failure criterion for the silicon photovoltaic cell corresponds to losing $10 \%$ of the maximum power through light-induced power degradation, occurrence of microcracks, increase in series resistance, decrease of shunt resistance, and so forth [12-14].

\section{Method}

The main goal of the accelerated life test is to reduce the testing time under simulated working conditions. In $\mathrm{DH}$ test the necessary time is around $2000 \mathrm{~h}$ and the target of the new methods is tens or some hundreds of hours.

There are many methods to perform the accelerated life test, but there is scarce research using light as ageing factor, because the majority use a climatic chamber and therefore the concentrated light is difficult to use [11]. The researchers had emulated the work conditions in concentrated light by injection of the forward current equivalent to the photogenerated current by the photovoltaic cell at the level of the desired concentration $[11,15]$. In this case the stress produced on the photovoltaic cells by the high concentrated light cannot be taken into consideration.

The paper presents a new method for the accelerated life test using the concentrated light obtained from a solar simulator with a xenon lamp (called ALTCL). Due to working conditions there are two stress factors: light and temperature.

The experiment set-up to apply the new method consists of the solar simulator, the photovoltaic cells, the measurement system, and the photovoltaic cells support cooled with water, which is provided with a variable flow of water [16].

2.1. Solar Simulator. The experiments were performed at Solar Technology Laboratory of Paul Scherrer Institute (PSI), Villigen, Switzerland, using the high-flux solar simulator (HFSS), which has ten xenon arc lamps cooled with high pressure water, Figure 1 . The highly concentrated light, similar to the solar radiation, is obtained in the focal plane using the lamps.

The lamp reflector is designed as a truncated ellipsoid $[17,18]$. The accelerated ageing test was performed using only one of the ten xenon arc lamps, which works at $10.6 \mathrm{~kW}$. The electric power of the lamp was maintained quasi-constant using an automatic system.

2.2. Photovoltaic Cells' Water Cooled Support. The photovoltaic cells' water cooling support allows the mounting of the four PV cells in different configurations and the maintaining of the PV cells temperature quasi-constant during the measurements under concentrated light [16]; see Figure 2.

The facility of the various mounting of the photovoltaic cells is necessary to have the PV cells illuminated with the same or with the different levels of the concentrated light.

The temperature of the photovoltaic cells can be adjusted using the levels of illumination and also the variable water flow which can be assured by the automatic pump system. The distribution of the illumination levels obtained with one xenon lamp at PSI is presented in Figure 3.

The photovoltaic cells were positioned so all of them are uniformly illuminated, with the same radiative flux, 190 suns. The shutter of the solar simulator was gradually opened until the temperature of the photovoltaic cells was $150^{\circ} \mathrm{C} \pm 2^{\circ} \mathrm{C}$.

2.3. Measurement System. The measurements were performed in concentrated light and under illumination at 1 sun.

The measurements in concentrated light were performed at PSI using a system based on cRIO from National Instruments and a module developed by our team which allows measuring the current voltage characteristics, $I-V$, for all four photovoltaic cells simultaneously and also their temperature. The photovoltaic cells' temperature was measured using a thermocouple for each of them. The maximum power can be determined by measuring $I-V$ characteristic of the photovoltaic cells. For measuring the current and voltage on the photovoltaic cells the NI 9227 and NI 9215 modules were used. The first module is used to measure the current through the photovoltaic cells and the second one is used for measuring their output voltage. These modules allow measuring all four channels at the same time. The dynamic load used for measuring $I-V$ characteristics of the photovoltaic cell is based on a large capacitor. The solar cell temperatures are measured with a NI 9211 module which allows sampling simultaneously for all four channels. The DIO (Digital Input Output) NI 9401 module is used for starting $I-V$ characteristic measurements. Between measurements of two consecutive $I-V$ characteristics a load can be applied to the photovoltaic cells. The applied load is based on a MOSFET which is controlled using the four analog outputs of the NI 9269 module. Some of the studied photovoltaic cells were maintained in the maximum power point regime while the others were maintained in the open circuit regime.

The measurements under 1-sun illumination were performed using the Autolab PGSTAT100. This system allows measuring $I-V$ characteristic under illumination using the potentiostat mode and also plotting and fitting the Nyquist diagram using the Fra (Frequency Response Analyzer) module.

2.4. Photovoltaic Cells. The photovoltaic cells chosen for the experiment are commercial monocrystalline silicon cells and In GaP/InGaAs/Ge multijunction cells. Four photovoltaic cells were tested, two of each type. In each pair of photovoltaic cells one of them was measured with load and one without load.

The reason of the choosing the monocrystalline silicon cells is that the lifetime is known. The monocrystalline silicon 


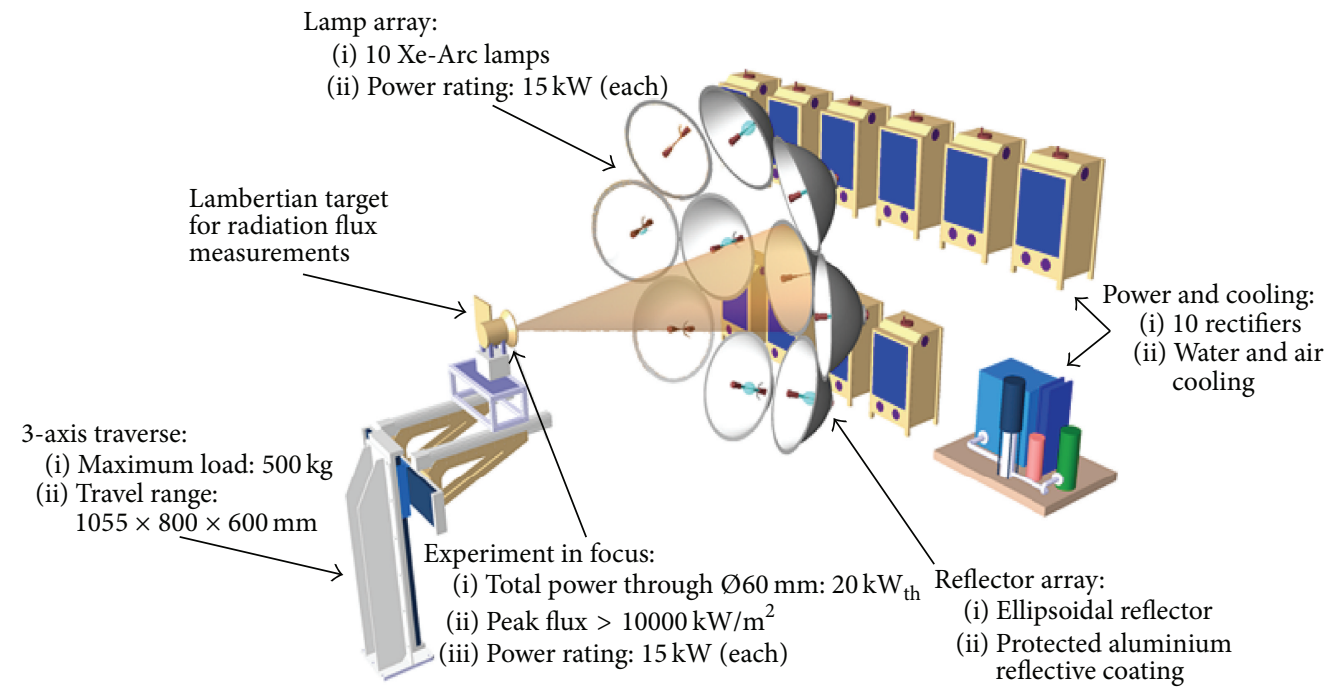

FIGURE 1: Schema of the solar simulator.

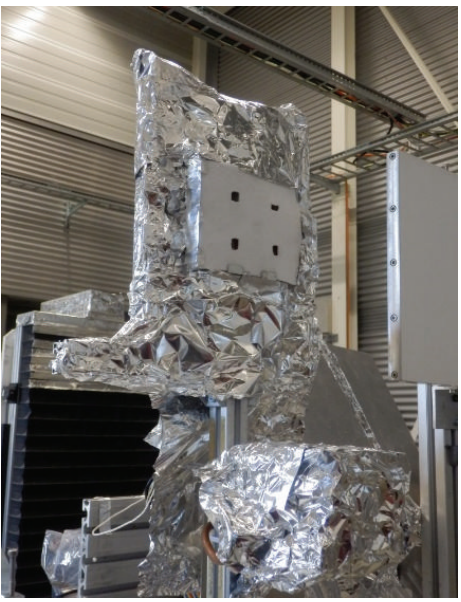

FIGURE 2: The photovoltaic cells' water cooled support with four PV cells.

photovoltaic cells were cut at $0.5 \mathrm{~cm} / 0.5 \mathrm{~cm}$ because the system can measure up to $5 \mathrm{~A}$ and for a good uniformity of the illumination. The short circuit current measured at 190 suns is $1.65 \mathrm{~A}$ and the open circuit voltage is $0.668 \mathrm{~V}$.

In GaP/InGaAs/Ge photovoltaic cells are made to work in concentrated light. Their structure is triple junction and the dimensions are $1 \mathrm{~cm} / 1 \mathrm{~cm}$. The short circuit current measured at 190 suns is $2.67 \mathrm{~A}$ and the open circuit voltage is $2.82 \mathrm{~V}$.

\section{Results and Discussion}

The desired temperature for the test, $150^{\circ} \mathrm{C}$, was obtained and maintained quasi-constant using only the concentrated light and the cooling system.

Núñez et al. [11] proposed two criteria for reliability of the photovoltaic cell: catastrophic failure, instant drop in power of the photovoltaic cells, and degradation failure, the power decreasing with more than $2.5 \%$ for the multijunction

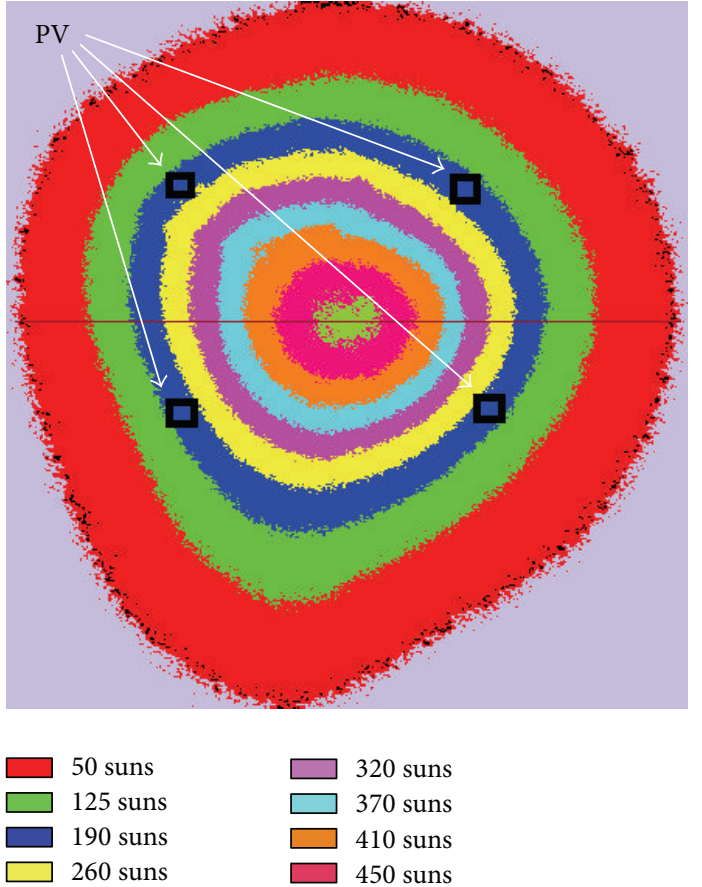

FIgURE 3: The radiative flux map and the positioning of the photovoltaic cells.

photovoltaic cells which work in concentrated light and more than $10 \%$ for the silicon photovoltaic cells.

The photovoltaic cells were subjected to 190 -sun concentrated light and $150^{\circ} \mathrm{C}$ for 35 hours and 7 hours per day and in the rest of day they were kept in darkness and at room temperature. After five days only the second criterion was observed.

The result of the accelerated ageing test of the monocrystalline silicon photovoltaic cell without load during the experiment is presented in Figure 4. The normalized power 


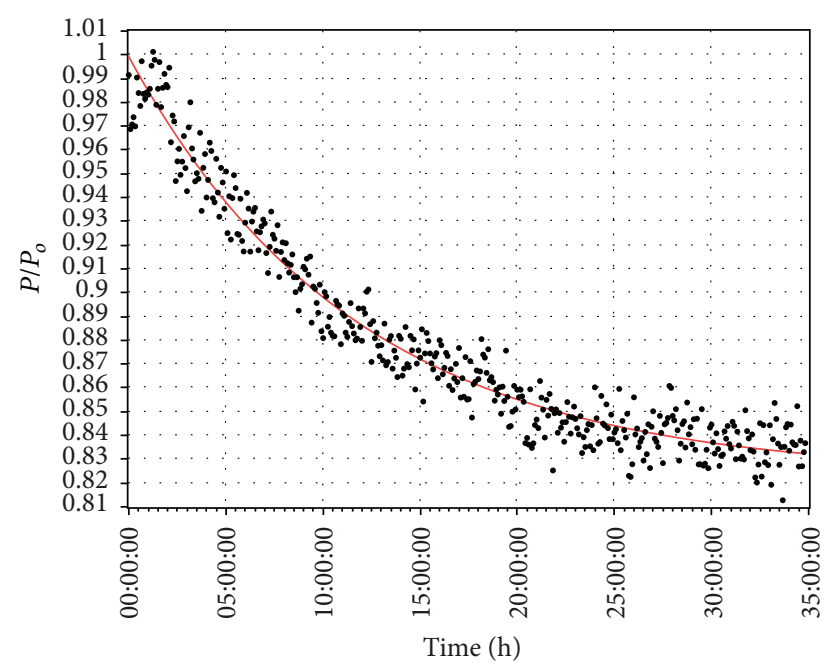

$\because P_{\max }$

$\triangle$ Fit

FIGURE 4: The normalized power of the monocrystalline photovoltaic cell without load evolution over time.

$P / P_{o}$, which is the ratio between the maximum power $P$ determined during the experiment and the initial maximum power $P_{o}$ of the photovoltaic cell at 190 suns and $150^{\circ} \mathrm{C}$, is represented over the time. The maximum power of the photovoltaic cell was determined using $I-V$ characteristic which was measured every five minutes.

The normalized power of the monocrystalline silicon photovoltaic cell without load decreases exponentially; see the red fitting curve from Figure 4, and the degradation failure criterion is reached after 10 hours. After 20 hours, an asymptotic decrease is observed in the normalized power. The normalized power after 35 hours is 0.83 , which means a decrease of $17 \%$; see Figure 4.

The normalized power InGaP/InGaAs/Ge multijunction photovoltaic cell without load decreases very slowly and after 35 hours it decreases only by $1.5 \%$.

The decreasing ratio of the normalized power for the photovoltaic cells with load during the ageing test, after 35 hours, was lower, $6 \%$ for the monocrystalline silicon (see Figure 5), and negligible for the multijunction photovoltaic cell.

The photovoltaic cells were analyzed in static regime, dc, and dynamic regime, ac, before and after the accelerated ageing test.

$I-V$ characteristics and power voltage, $P-V$, characteristics are measured for each photovoltaic cell. The measurements were realized with Autolab, under illumination at $1000 \mathrm{~W} / \mathrm{m}^{2}$ irradiance (1 sun) and at this time the temperature of the photovoltaic cells is maintained constant with thermostat at $25^{\circ} \mathrm{C} \pm 0.5^{\circ} \mathrm{C}$.

Figure 6 shows $I-V$ and $P-V$ characteristics measured for the monocrystalline silicon photovoltaic cell without load before and after the accelerated test. By analyzing the results it is observed that the short circuit current, $I_{\mathrm{sc}}$, decreases with $3.9 \% \pm 0.1 \%$, the open circuit voltage decreases with $5.4 \pm$ $0.1 \%$, and the maximum power decreases with $18.2 \% \pm 0.2 \%$.

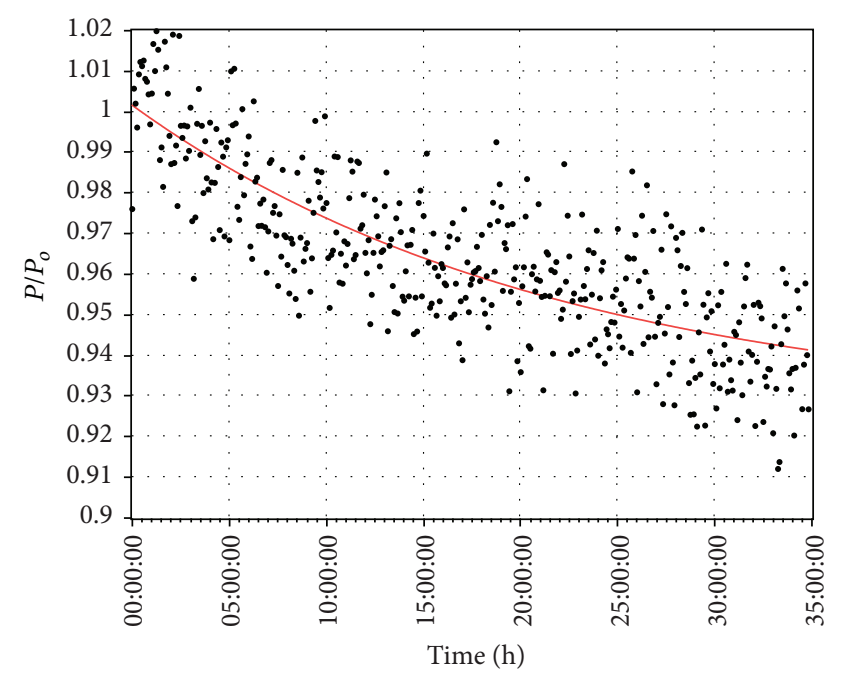

$\because P_{\max }$

FIGURE 5: The normalized power of the monocrystalline photovoltaic cell with load evolution over time.

The shape of $I-V$ characteristic around the knee (the maximum power point), for the aged photovoltaic cell, shows an important modification. This can be explained by the increasing of the series resistance, $R_{s}$, and the decreasing of the shunt resistance, $R_{\mathrm{sh}}$.

$I-V$ and $P-V$ characteristics measured for the InGaP/ InGaAs/Ge multijunction photovoltaic cell without load before and after the accelerated test are presented in Figure 7. The maximum power decreases with $1.5 \% \pm 0.1 \%$, whereas $I_{\mathrm{sc}}$ and $V_{\mathrm{oc}}$ remain quasi-constant after the ageing process. The shape of $I-V$ characteristic measured after the ageing process remains almost unchanged, only the effect of the slight increase in the series resistance being observed.

The impedance spectroscopy $[19,20]$ with the frequency domain technique is used to analyze the parameters of the photovoltaic cells in dynamic regime before and after the ageing process. An ac pure sinusoidal signal with amplitude smaller than the thermal voltage, $(k T / e)$, is superposed on the dc bias signal. The measurements were performed at bias voltage equal to $V_{\max }$, the voltage corresponding to the maximum power point. The photovoltaic cells were maintained at $25^{\circ} \mathrm{C} \pm 0.5^{\circ} \mathrm{C}$ and were illuminated at 1 sun.

The Nyquist diagrams, before and after the ageing process, for the monocrystalline silicon photovoltaic cell without load are presented in Figure 8 and those for the InGaP/ InGaAs/Ge multijunction photovoltaic cell without load are presented in Figure 9. The important ac parameters of the photovoltaic cells are obtained using the fitting procedure with the equivalent ac circuit and they are presented in Table 1.

The results obtained for the ac parameters of the photovoltaic cells confirm analysis for the behavior of the photovoltaic cells in static regime. The series resistance strongly increases for the monocrystalline silicon photovoltaic cell, 


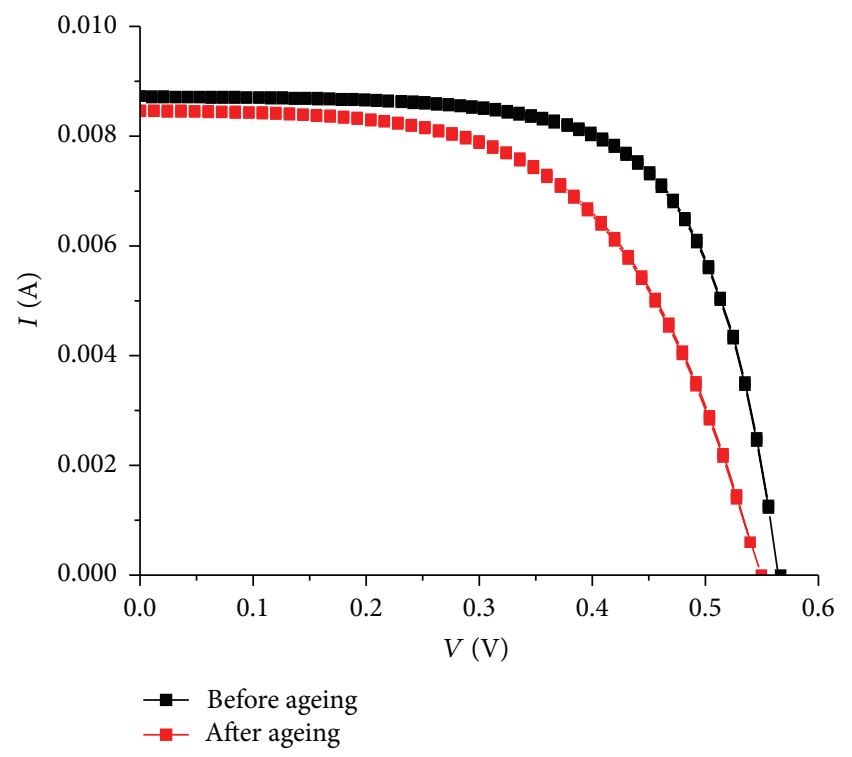

(a)

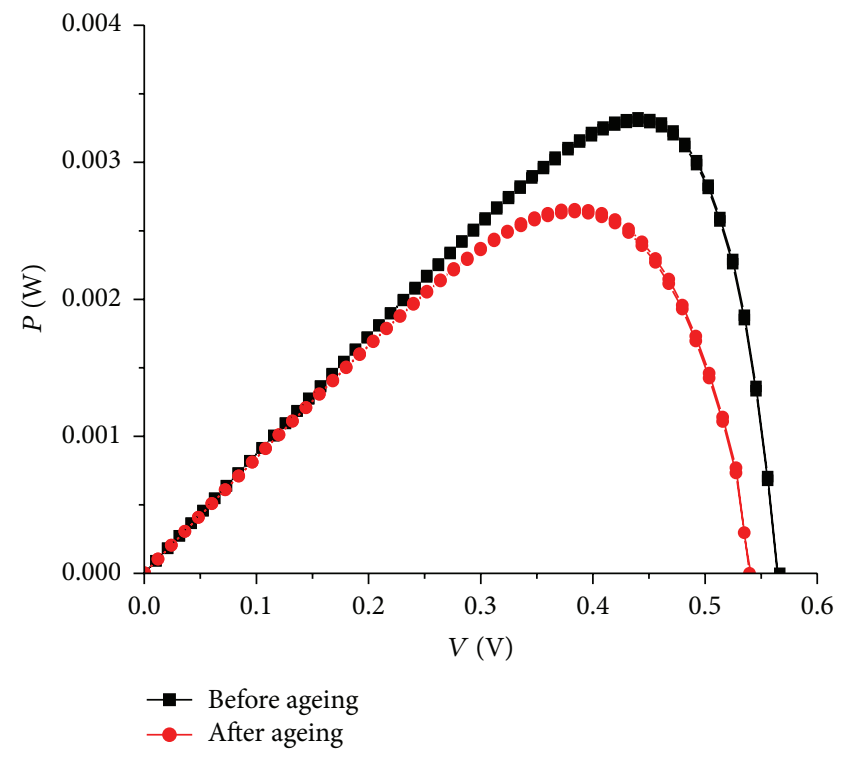

(b)

FIGURE 6: The monocrystalline silicon photovoltaic cell without load before and after ageing process. (a) $I-V$ characteristics; (b) $P$ - $V$ characteristics.

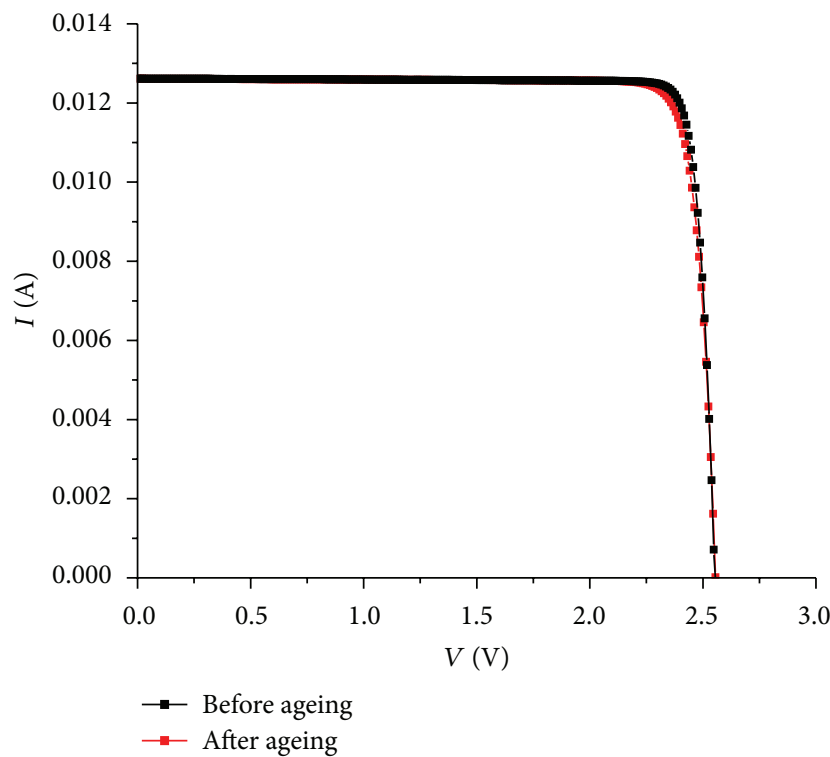

(a)

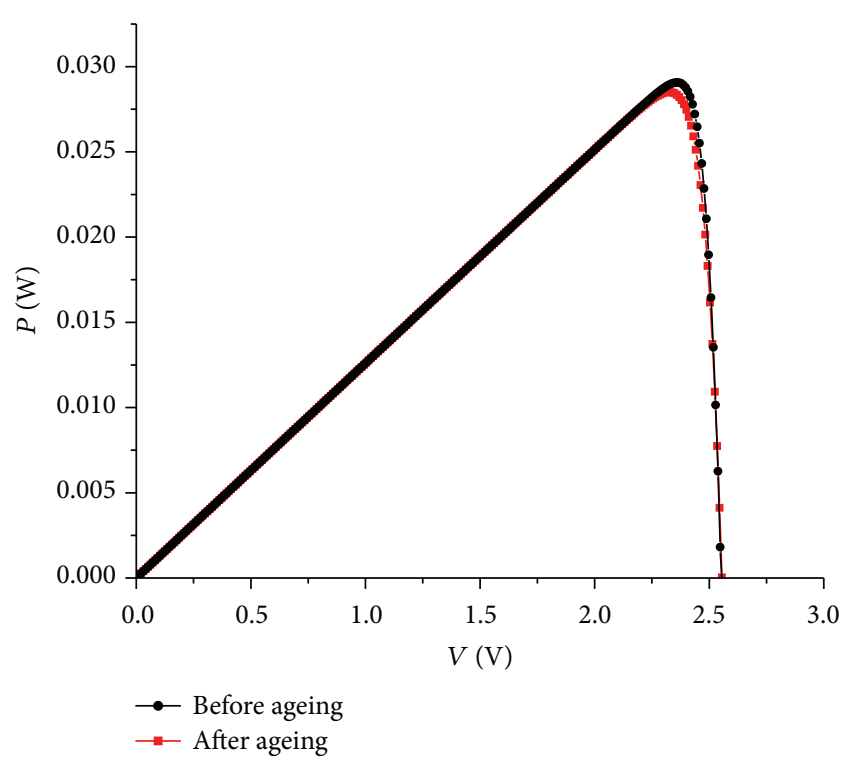

(b)

Figure 7: The InGaP/InGaAs/Ge multijunction photovoltaic cell without load before and after ageing process. (a) $I-V$ characteristics; (b) $P-V$ characteristics.

TABLE 1: The ac parameters of the photovoltaic cells at $1000 \mathrm{~W} / \mathrm{m}^{2}$ and $25^{\circ} \mathrm{C}$.

\begin{tabular}{lcccc}
\hline Type of photovoltaic cell & Ageing test & $R_{s}[\Omega]$ & $R_{p}[\Omega]$ & $C[\mathrm{nF}]$ \\
\hline \multirow{2}{*}{ Monocrystalline silicon without load } & Before & $0.23 \pm 0.01$ & $49.67 \pm 0.2$ & $644.3 \pm 3.5$ \\
& After & $0.76 \pm 0.01$ & $24,23 \pm 0.16$ & $432.4 \pm 2.5$ \\
\hline \multirow{2}{*}{ Monocrystalline silicon with load } & Before & $0.22 \pm 0.01$ & $49.71 \pm 0.2$ & $642.3 \pm 3.5$ \\
& After & $0.45 \pm 0.01$ & $38,23 \pm 0.16$ & $552.4 \pm 2.5$ \\
\hline \multirow{2}{*}{ InGaP/InGaAs/Ge without load } & Before & $0.87 \pm 0.012$ & $18.42 \pm 0.12$ & $(19.43 \pm 0.1) * 10^{3}$ \\
& After & $0.881 \pm 0.012$ & $18.39 \pm 0.12$ & $(19.42 \pm 0.1) * 10^{3}$ \\
\hline
\end{tabular}




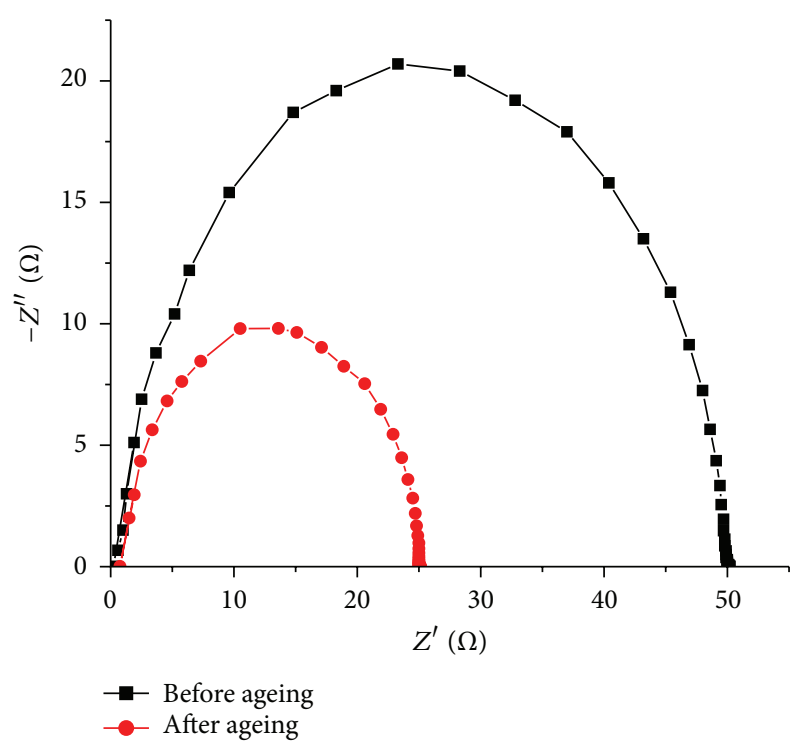

FIGURE 8: Nyquist plot of the monocrystalline silicon photovoltaic cell without load before and after ageing process.

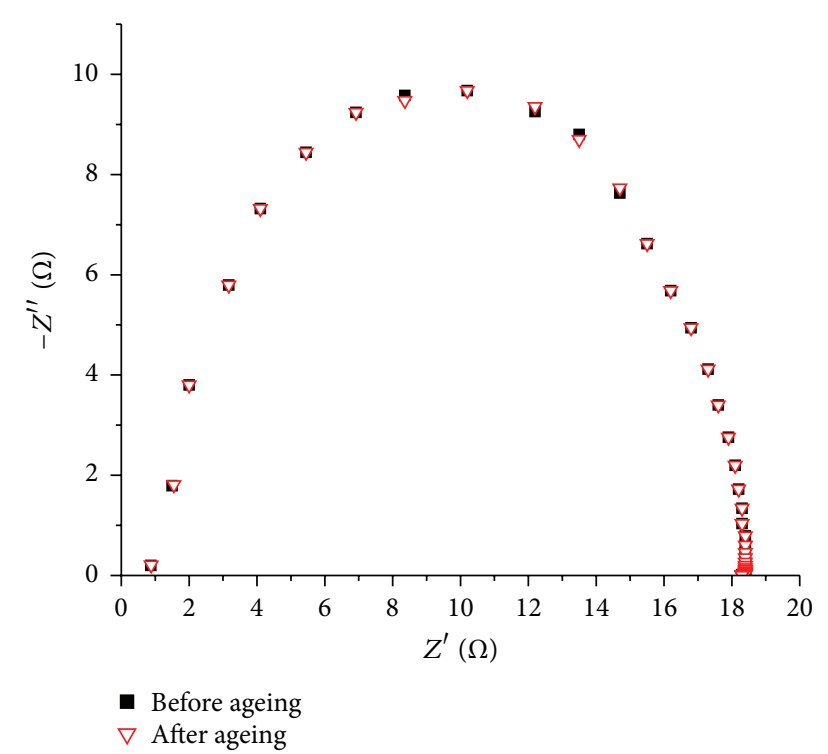

Figure 9: Nyquist plot of the InGaP/InGaAs/Ge multijunction photovoltaic cell without load before and after ageing process.

whereas for the multijunction photovoltaic cell it slightly increases. The same behavior is determined for the decrease of the shunt resistance and for the capacitance.

\section{Conclusions}

A new method for the accelerated life test of the photovoltaic cells was developed and verified. The novelty of the method is the use of only concentrated light and the cooling system so as to have two ageing factors: the light and the temperature.

The duration of the life test is reduced considerably, for example, 10-20 hours for the monocrystalline silicon photovoltaic cells without load at 190 suns. For monocrystalline silicon cell with load the degradation after $35 \mathrm{~h}$ at the same illumination is $6 \%$. The maximum power of InGaP/InGaAs/Ge multijunction cell without load at 190 suns after 35 hours decreases with $1.5 \%$, which means it does not reach the limit of the degradation failure.

The maximum power of the photovoltaic cells with load decreases slighter than the maximum power of the photovoltaic cells without load, which proves that lifetime of the photovoltaic panels increases if they work in load.

The parameters of the photovoltaic cells were analyzed in static and dynamic regime at 1 sun and $25^{\circ} \mathrm{C}$ using $I-V$ and $P-V$ characteristics and the Nyquist diagrams. The behavior of the short circuit current, open circuit voltage, maximum power, series and parallel resistance, and capacitance before and after the ageing process was studied.

The future research will consist of increasing the duration of the life test for the multijunction photovoltaic cells until the limit of the degradation failure criterion is reached and also we will apply the method validated by present work to test other type of photovoltaic cells.

\section{Competing Interests}

The authors declare that they have no competing interests.

\section{Acknowledgments}

Financial support by the Access to Research Infrastructures activity in the 7th Framework Programme of the EU (SFERA 2 Grant Agreement no. 312643) is gratefully acknowledged. The authors are thankful to Y. Baeuerle, D. Wuillemin, and C. Wieckert as well as further coworkers from the Solar Technology Laboratory of Paul Scherrer Institute, Villigen, Switzerland, where all the measurements in concentrated light were performed. They hereby acknowledge the structural funds project PRO-DD (POS-CCE, O.2.2.1., ID 123, SMIS 2637, no. $11 / 2009$ ) for providing a part of the infrastructure used in this work.

\section{References}

[1] M. A. Green, K. Emery, Y. Hishikawa, W. Warta, and E. D. Dunlop, "Solar cell efficiency tables (version 44)," Progress in Photovoltaics: Research and Applications, vol. 23, pp. 1-9, 2015.

[2] M. I. Ahmed, A. Habib, and S. S. Javaid, "Perovskite solar cells: potentials, challenges, and opportunities," International Journal of Photoenergy, vol. 2015, Article ID 592308, 13 pages, 2015.

[3] US Department of Energy, Sandia, and NREL, "Accelerated aging testing and reliability in photovoltaics. Solar energy technology program," 2008.

[4] D. C. Jordan and S. R. Kurtz, "Photovoltaic degradation ratesan analytical review," Progress in Photovoltaics: Research and Applications, vol. 21, no. 1, pp. 12-29, 2013.

[5] A. Phinikarides, N. Kindyni, G. Makrides, and G. E. Georghiou, "Review of photovoltaic degradation rate methodologies," Renewable and Sustainable Energy Reviews, vol. 40, pp. 143-152, 2014. 
[6] J. R. González, M. Vázquez, N. Núñez, C. Algora, I. Rey-Stolle, and B. Galiana, "Reliability analysis of temperature step-stress tests on III-V high concentrator solar cells," Microelectronics Reliability, vol. 49, no. 7, pp. 673-680, 2009.

[7] G. J. Lin, L. J. Wang, J. Q. Liu, W. P. Xiong, M. H. Song, and Z. H. Wu, "Accelerated aging tests of high concentration multijunction solar cells," Procedia Environmental Sciences, vol. 11, pp. 1147-1152, 2011

[8] C. R. Osterwald, T. J. McMahon, and J. A. del Cueto, "Electrochemical corrosion of $\mathrm{SnO}_{2}: \mathrm{F}$ transparent conducting layers in thin-film photovoltaic modules," Solar Energy Materials and Solar Cells, vol. 79, no. 1, pp. 21-33, 2003.

[9] E. Kaplani, "Detection of degradation effects in field-aged c-Si solar cells through IR thermography and digital image processing," International Journal of Photoenergy, vol. 2012, Article ID 396792, 11 pages, 2012.

[10] M. Vázquez and I. Rey-Stolle, "Photovoltaic module reliability model based on field degradation studies," Progress in Photovoltaics: Research and Applications, vol. 16, no. 5, pp. 419-433, 2008.

[11] N. Núñez, J. R. González, M. Vázquez, C. Algora, and P. Espinet, "Evaluation of the reliability of high concentrator GaAs solar cells by means of temperature accelerated aging tests," Progress in Photovoltaics: Research and Applications, vol. 21, no. 5, pp. 1104-1113, 2013.

[12] M. Paggi, I. Berardone, A. Infuso, and M. Corrado, "Fatigue degradation and electric recovery in Silicon solar cells embedded in photovoltaic modules," Scientific Reports, vol. 4, article 4506, pp. 1-7, 2014.

[13] D. De Graaff, R. Lacerda, and Z. Campeau, "Degradation mechanisms in Si module technologies observed in the field; their analysis and statistics," in Proceedings of the NREL Photovoltaic Module Reliability Workshop, Golden, Colo, USA, February 2011.

[14] P. Basnyat, B. Sopori, S. Devayajanam et al., "Experimental study to separate surface and bulk contributions of lightinduced degradation in crystalline silicon solar cells," Emerging Materials Research, vol. 4, no. 2, pp. 239-246, 2015.

[15] C. Algora, "Reliability of III-V concentrator solar cells," Microelectronics Reliability, vol. 50, no. 9-11, pp. 1193-1198, 2010.

[16] D. T. Cotfas, P. A. Cotfas, D. Floroian, L. Floroian, and M. Cernat, "Ageing of photovoltaic cells under concentrated light," in Proceedings of the 2015 Intl Aegean Conference on Electrical Machines \& Power Electronics (ACEMP '15) and Intl Conference on Optimization of Electrical \& Electronic Equipment (OPTIM) \& 2015 Intl Symposium on Advanced Electromechanical Motion Systems (ELECTROMOTION '15), Side, Turkey, September 2015.

[17] J. Petrasch, P. Coray, A. Meier et al., "A novel 50 kW 11,000 suns high-flux solar simulator based on an array of xenon arc lamps," ASME Journal of Solar Energy Engineering, vol. 129, no. 4, pp. 405-411, 2007.

[18] I. Alxneit and H. Schmit, "Spectral characterization of PSI's high-flux solar simulator," Journal of Solar Energy Engineering, vol. 134, no. 1, Article ID 011013, 2012.

[19] M. Toivola, J. Halme, L. Peltokorpi, and P. Lund, "Investigation of temperature and aging effects in nanostructured dye solar cells studied by electrochemical impedance spectroscopy," International Journal of Photoenergy, vol. 2009, Article ID 786429, 15 pages, 2009.

[20] D. T. Cotfas, P. A. Cotfas, and S. Kaplanis, "Methods and techniques to determine the dynamic parameters of solar cells: review," Renewable and Sustainable Energy Reviews, vol. 61, pp. 213-221, 2016. 

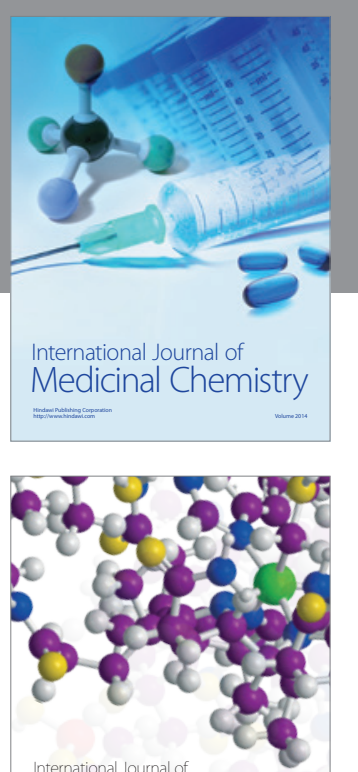

Carbohydrate Chemistry

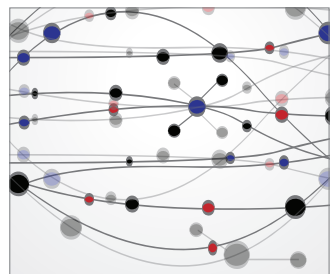

The Scientific World Journal
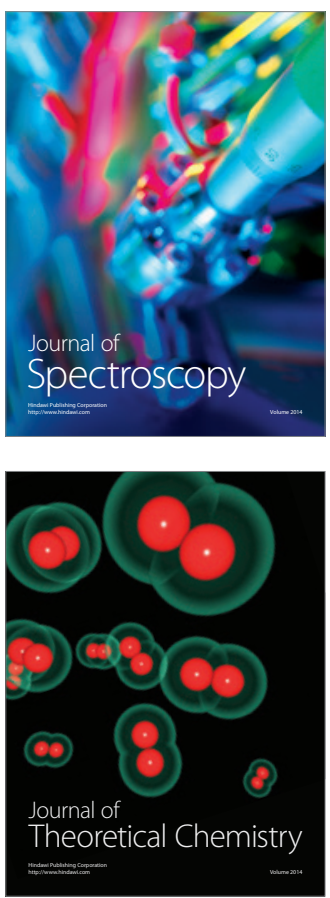
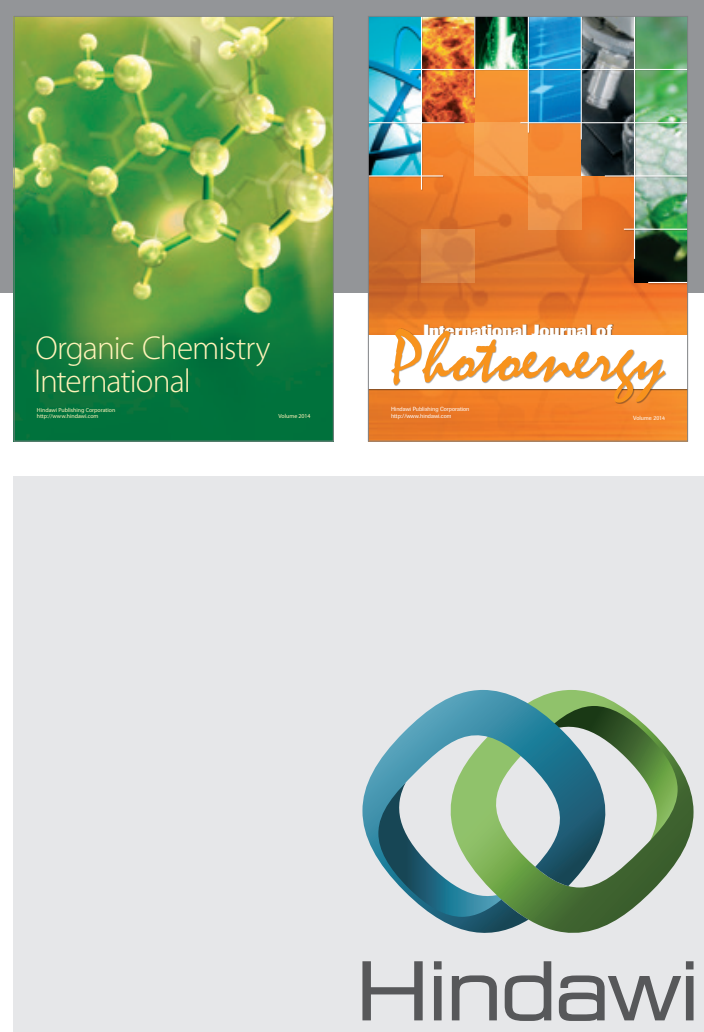

Submit your manuscripts at

http://www.hindawi.com

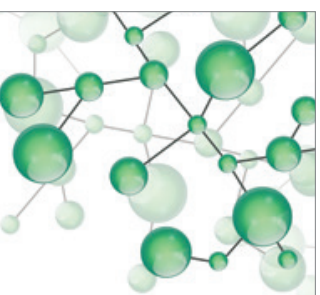

International Journal of

Inorganic Chemistry

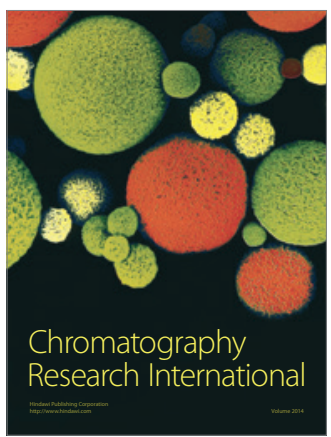

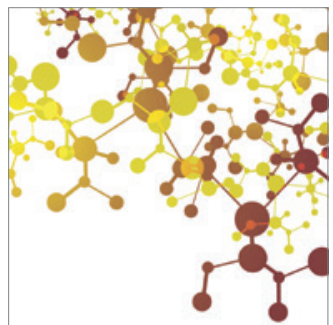

Applied Chemistry
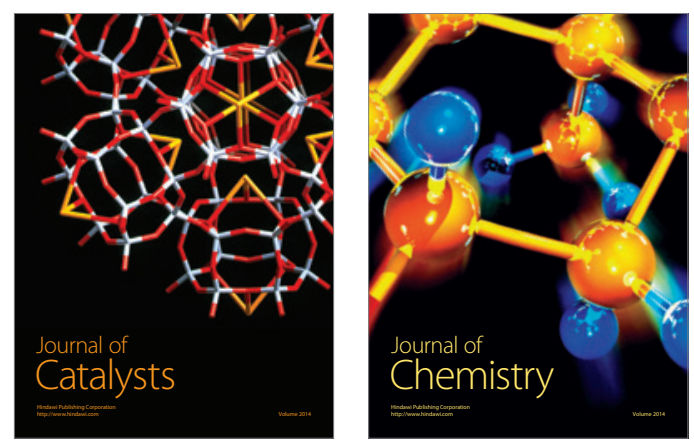
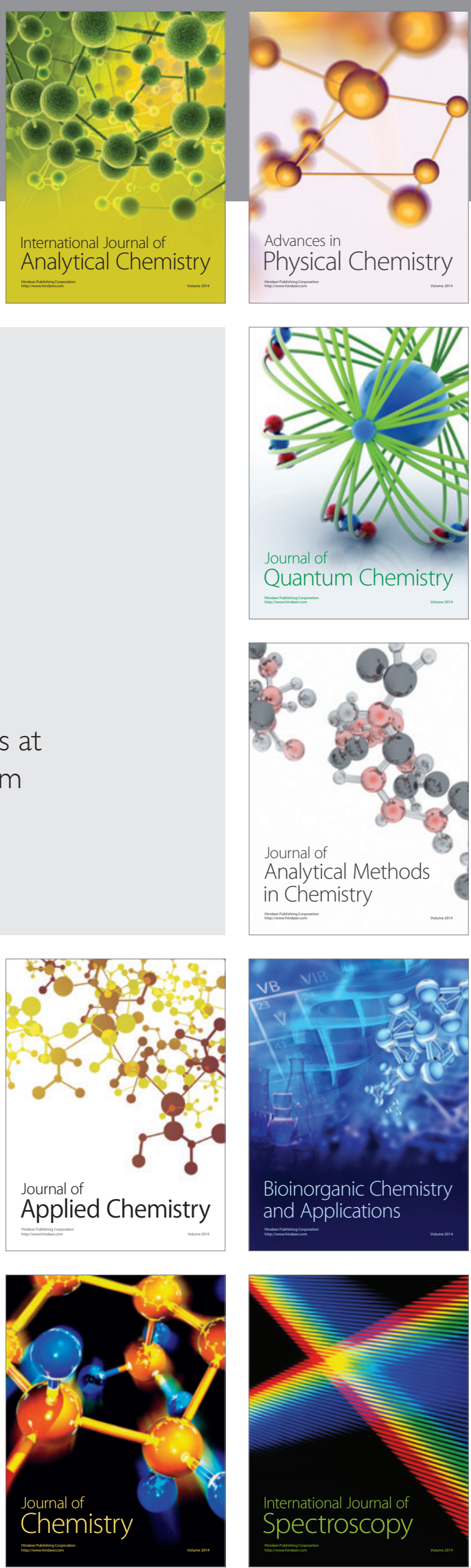